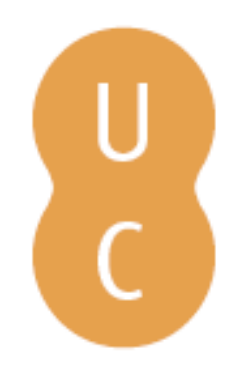

\title{
nombalina
}

Ricardo Jorge e as relações entre Portugal, Brasil e África: o caso da febre amarela

Autor(es): Benchimol, Jaime Larry

Publicado por: Imprensa da Universidade de Coimbra

URL

persistente:

URI:http://hdl.handle.net/10316.2/38452

DOI: $\quad$ DOI:http://dx.doi.org/10.14195/978-989-26-0764-1_16

Accessed : $\quad$ 26-Apr-2023 11:43:20

A navegação consulta e descarregamento dos títulos inseridos nas Bibliotecas Digitais UC Digitalis, UC Pombalina e UC Impactum, pressupõem a aceitação plena e sem reservas dos Termos e Condições de Uso destas Bibliotecas Digitais, disponíveis em https://digitalis.uc.pt/pt-pt/termos.

Conforme exposto nos referidos Termos e Condições de Uso, o descarregamento de títulos de acesso restrito requer uma licença válida de autorização devendo o utilizador aceder ao(s) documento(s) a partir de um endereço de IP da instituição detentora da supramencionada licença.

Ao utilizador é apenas permitido o descarregamento para uso pessoal, pelo que o emprego do(s) título(s) descarregado(s) para outro fim, designadamente comercial, carece de autorização do respetivo autor ou editor da obra.

Na medida em que todas as obras da UC Digitalis se encontram protegidas pelo Código do Direito de Autor e Direitos Conexos e demais legislação aplicável, toda a cópia, parcial ou total, deste documento, nos casos em que é legalmente admitida, deverá conter ou fazer-se acompanhar por este aviso.

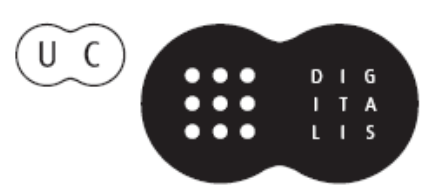


Casa de Oswaldo Cruz

Fundação Oswaldo Cruz

jbench@oi.com.br

\section{Ricardo Jorge e as Relaçốes Entre Portugal, Brasil e África: O Caso da Febre Amarela ${ }^{1}$}

\section{Jaime Larry Benchimol}

Ricardo Jorge veio ao Brasil pela primeira vez em meados de 1929, para participar das comemorações do Centenário da Academia Nacional de Medicina. Suas conferências foram publicadas no ano seguinte com o título Brasil! Brasil!, em estabelecimento lisboeta curiosamente chamado Empresa Literária Fluminense 2 . "O brasilismo, e chamo assim a cultura, o culto, o amor das coisas do Brasil, conquista-me já tarde”, declarou Ricardo Jorge aos letrados cariocas, lamentando não haver estado antes no Brasil ${ }^{3}$. Em outro trabalho da mesma época, revela os contatos intensos que estabeleceu então com as comunidades médico-científicas de São Paulo e do Rio de Janeiro ${ }^{4}$. Com Carlos Chagas, já mantinha relações estreitas. Eram ambos delegados de seus países no Office International d'Hygiène Publique e no Comitê de Higiene da Liga das Nações. Diretor do Instituto Oswaldo Cruz de 1917 até o fim de sua vida (1934), Chagas estivera em Lisboa em fins de 1924, quando chefiava o Departamento Nacional de Saúde Pública. Em 1 de novembro, na Sociedade de Ciências Médicas da capital portuguesa, proferira conferência sobre a tripanossomíase humana batizada com seu nome .

Naquela mesma semana, Portugal festejava o médico e escritor Afrânio Peixoto, professor da Faculdade de Medicina do Rio de Janeiro, agraciado com o título de doutor

${ }^{1}$ Esse trabalho coincide em larga medida com artigo submetido à Revista Estudos do Século XX, n. ${ }^{\circ} 12$ (no prelo), editada pela Imprensa da Universidade de Coimbra (IUC), em parceria com o Centro de Estudos Interdisciplinares do Século XX - CEIS20. Mudanças foram feitas somente na parte final do texto.

${ }^{2}$ Palavra que designa no vernáculo brasileiro natural ou habitante do Rio de Janeiro.

${ }^{3}$ JORGE, Ricardo - 1930. Brasil! Brasil! Conferencia na Academia Brasileira de Letras sobre o brasilismo em Portugal e alocuções proferidas no Rio e em S. Paulo de 30-6 a 25-7 de 1929. Lisboa: Empresa Literária Fluminense, p. 18.

${ }^{4}$ JORGE, Ricardo 1930b - La fièvre jaune et la campagne sanitaire a Rio de Janeiro (1928-1929). Paris: Office International d'Hygiene Publique. (Extrait du Bulletin mensuel de l'Office International d'Hygiène publique tome XXII, année 1930, fasc. 3).

${ }^{5}$ FUNDAÇÃO OSWALDO CRUZ/CASA DE OSWALDO CRUZ/DEPARTAMENTO DE ARQUIVO E DOCUMENTAÇÃO/FUNDO CARLOS CHAGAS/ Grupo Vida Pessoal. Relações Familiares e Produção de Retratos do Titular - Série Álbuns de Recortes de Jornais/Livro IV, p. 104: “Um sábio brasileiro". A Notícia, 27.11.1924. Segundo o jornal, o nome de Chagas era há muito respeitado entre os estudantes portugueses, fato que atribuía sobretudo ao dr. Jorge Monjardino, que tomara a peito "realizar um mais estreito e completo intercâmbio científico entre as duas naçōes atlânticas”, e Ricardo Jorge, "tão grande escritor como grande médico e sempre difícil nas suas admirações". $\mathrm{Na}$ mesma fonte encontram-se vários outros recortes concernentes à estada de Carlos Chagas em Lisboa: 
honoris causa pela Faculdade de Letras da Universidade de Lisboa e eleito membro da Academia de Ciências de Portugal. Júlio Dantas, presidente da Academia, lamentou que Chagas houvesse embarcado na véspera, sem assistir à investidura de Afrânio Peixoto. "Mas, ao abraçar no Rio o seu colega (...) não deixará, decerto, de lhe dizer com que carinhoso respeito o nome do romancista da Bugrinha é hoje proferido em Portugal". ${ }^{6}$

Aquele desencontro não foi por acaso. Em 30 de novembro de 1922, na Academia Nacional de Medicina do Rio de Janeiro, em discurso com que recebeu como membro titular outro cientista do Instituto Oswaldo Cruz, Afrânio Peixoto havia declarado: "Poderíeis ter achado alguns mosquitos, inventado doença rara e desconhecida, doença de que se falasse muito mas quase ninguém conhecesse os doentes, encantoada lá num viveiro sertanejo de vossa província, que magnanimamente distribuiríeis por alguns milhôes de vossos patrícios, acusados de cretinos". ${ }^{7}$

A farpa trouxe à tona críticas que diziam respeito à autoria da descoberta de Chagas, à extensão da doença produzida pelo Trypanosoma cruzi - sugerida pelo nome tripanossomíase americana - e sua relação com o bócio, indicada por outro nome dado à Doença de Chagas, tiroidite parasitária. Com base no registro desse suposto sinal patognômico, os propagadores da descoberta asseguravam que milhôes de brasileiros estariam infetados pelo tripanossomo. Em 6 de dezembro de 1923, Carlos Chagas proferiu o discurso que, formalmente, encerrou a polêmica. Uma década depois (1934-5) seriam publicados os trabalhos de Salvador Mazza e Cecílio Romana. Este descobrira que o Trypanosoma cruzi com freqüência invadia o organismo pelo globo ocular, dando origem à inflamação da conjuntiva, o chamado 'sinal de Romaña'; e Mazza confirmara que penetrava também pela pele, formando tumores chamados chagomas. Na Argentina, descreveriam mais de mil casos humanos da doença, desencadeando o reflorescimento dos estudos sobre ela em toda a América do Sul. ${ }^{8}$

Que repercussões tiveram em Portugal essa descoberta e suas controvérsias? E que ressonâncias tiveram no Brasil as investigaçōes sobre a doença do sono, a outra tripanossomíase humana conhecida, que tanta importância teve para a medicina tropical portuguesa ${ }^{9}$ em virtude das colônias africanas? Eis aí um tema a desbravar na história das relações médico-científicas entre Brasil e Portugal.

Outras figuras representativas da medicina brasileira estiveram em Portugal naqueles anos do entreguerras ou interagiram com médicos portugueses em congressos na Europa e América. Médicos lusitanos, por sua vez, estiveram no Brasil, inclusive Júlio Dantas, que, no já citado artigo de 1924, aludia a projeto de um congresso médico luso-brasileiro e à uniformização da linguagem médica nos dois países.

${ }^{6}$ FUNDAÇÃO OSWALDO CRUZ... - Série Álbuns de Recortes de Jornais/Livro IV, p. 137: DANTAS, Júlio - "Dois brasileiros ilustres". Correio da Manhã, s.d.

${ }^{7}$ Boletim da Academia de Medicina, n. ${ }^{\circ}$ 20, 1922, p. 723. In RIBEIRO, Leonídio 1950 - Afrânio Peixoto. Rio de Janeiro: Ediçōes Condé, p. 190.

${ }^{8}$ A esse respeito consultar CHAGAS FILHO, Carlos 1993 - Meu pai. Rio de Janeiro: COC/FIOCRUZ; e sobretudo KROPF, Simone P. 2009 - Doença de Chagas, doença do Brasil: ciência, saúde e nação (1909-1962). Rio de Janeiro: Edição Fiocruz.

${ }^{9}$ A esse respeito ver AMARAL, Isabel 2008 - "The emergence of tropical medicine in Portugal: The School of Tropical Medicine and the Colonial Hospital of Lisbon (1902-1935) ". Dynamis. Madrid. 0211-9536. N.o 28, pp. 301-328. 
No entanto, em uma das conferências proferidas cinco anos depois no Rio de Janeiro, Ricardo Jorge reconhecia: "Vivemos num relativo afastamento". Letrados e cientistas brasileiros "em regra, se desembarcam em Lisboa, é o norte da Europa que demandam". Por outro lado, os portugueses, mesmo os instruídos, conheciam mal a literatura e a produção mental do Brasil. ${ }^{10}$

Ricardo Jorge esteve no Rio de Janeiro, então a capital do Brasil, quando soavam os últimos acordes da campanha contra a febre amarela, que irrompera aí em 1928, causando profundo abalo nos paradigmas e aparatos há décadas mobilizados contra a doença. Como delegado de Portugal no Office International d'Hygiène Publique, estava envolvido com as discussóes sobre a doença em África. Em outubro de 1929, divulgou extensa comunicação intitulada La fièvre jaune et la campagne sanitaire a Rio de Janeiro (1928-1929). ${ }^{11}$ Clementino Fraga, sucessor de Chagas na chefia do Departamento Nacional de Saúde Pública, agradeceu aquela homenagem à higiene brasileira e referiu-se a um filme recém-produzido sobre a campanha, pedindo ao colega português que o disseminasse. Ricardo Jorge tivera já a oportunidade de ver o próprio Oswaldo Cruz em ação em outro filme projetado em 1914, em evento internacional. ${ }^{12}$

O que mostravam? Cenas em parte parecidas, pois a campanha em 1928-1929 era uma reedição daquela executada pela primeira vez na capital brasileira, no início do século. Digo em parte porque a virada dos anos 1920 para os 1930 caracterizou-se por grandes inflexões na história internacional da febre amarela, na história política e social do Brasil e na história de suas relações com Portugal.

Por ora, vou puxar um fio apenas dessa trama. No começo do século, treze anos após a proclamação da República no Brasil (15 de Novembro de 1889), Oswaldo Cruz contou com condições favoráveis para implementar aquela operação draconiana que bem sugere a expressão 'campanha sanitária'. Os conflitos suscitados pelo saneamento do Rio e pela reforma urbana concomitante foram reprimidos e estigmatizados como manifestaçóes de incultura e atraso colonial, estigmas, diga-se de passagem, com forte conotação antilusitana. ${ }^{13} \mathrm{O}$ regresso da doença ao Rio de Janeiro, em 1928-9 foi encarado como sintoma da incompetência das oligarquias para administrar a nação. A Primeira República logo seria encerrada pela chamada Revolução de 1930.

“Tristíssimo efeito das revoluçôes!” — escreveu Ricardo Jorge a Fraga — “(..) A ingratidão pública - nada há de mais ferozmente estúpido. Conheço-a de experiência há mais de 30 anos, a quando da peste do Porto". ${ }^{14}$

\footnotetext{
${ }^{10}$ JORGE, Ricardo - Brasil! Brasil! ... p. 83.

${ }^{11} \mathrm{O}$ trabalho é reproduzido em JORGE, Ricardo - 1938 Fièvre Jaune. Arquivos do Instituto de Higiene Dr. Ricardo Jorge, vol. IV, Fasc. 1. Lisboa: Tip. Colonial, pp. 11 a 38.

${ }^{12}$ Correspondência entre Ricardo Jorge e Clementino Fraga revela os laços estreitos que estabeleceram então: FUNDAÇĀO OSWALDO CRUZ/CASA DE OSWALDO CRUZ/DEPARTAMENTO DE ARQUIVO E DOCUMENTAÇĀO/ Fundo Clementino Fraga, Pasta CF/COR/19291010 (5 cartas). Na carta de 10de outubro de 1929, escrita pelo médico português em Lisboa, lê-se: "A conquista de amigos é o maior bem da vida. (...) A si trouxe-o na cabeça e no coração; o higienista admirei-o, e o homem encantou-me".

${ }^{13}$ BENCHIMOL, Jaime Larry 2010 - "Rio de Janeiro: da urbe colonial à cidade dividida”. In PINHEIRO, Augusto Ivan de Freitas (org.). Rio de Janeiro: cinco séculos de história e transformaçôes urbanas. Rio de Janeiro: Casa da Palavra, pp. 163-203.

${ }^{14}$ FUNDAÇÃO OSWALDO CRUZ ... Fundo Clementino Fraga, Pasta CF/COR/19291010 - carta de Ricardo Jorge a Clementino Fraga, em 6 de abril de 1931 (Lisboa)
} 
Ricardo Jorge relacionava o movimento que levou Getúlio Vargas ao poder à traumática experiência que tivera em sua cidade natal. Chefiava então o serviço municipal de higiene do Porto ao irromper lá uma epidemia denunciada por mortandade incomum de ratos. As evidências clínicas e as investigações anatomopatológicas e microbiológicos levaram-no a reconhecer que o recém-descoberto bacilo da peste bubônica circulava em seus hospedeiros animais naquela cidade portuária. O comércio internacional e os fluxos migratórios vinham espalhando a peste pelo mundo, e no rastro dela seguiam os microbiologistas. Ao ser diagnosticada a peste no Porto, para lá se deslocaram Léon Charles Albert Calmette e outro 'pasteuriano', Alexandre Tourelli Salimbeni, com o intuito de avaliar o soro antipestoso que acabava de ser desenvolvido. Os resultados obtidos em colaboração com Ricardo Jorge logo ganharam repercussão internacional. ${ }^{15}$

Ele então submeteu a cidade às medidas draconianas que conhecem bem os que leram o célebre romance de Camus sobre a peste no norte da África, ${ }^{16}$ e que não foram muito diferentes das medidas implementadas no Brasil, no porto de Santos, quando para lá a peste foi transportada em vapores lotados de emigrantes oriundos do Porto.

A dificuldade de obter o soro de Yersin e a vacina de Haffkine levou o governo paulista a criar um laboratório para fabricá-los na Fazenda Butantan. Recém-chegado do Instituto Pasteur de Paris, Oswaldo Cruz assumiu a direção de outro Instituto Soroterápico, criado na fazenda de Manguinhos, no Rio de Janeiro. Daí à chefia da saúde pública no governo de Francisco de Paula Rodrigues Alves (1902-1906) foi um passo ${ }^{17}$.

No Porto, a crise sanitária teve outro desfecho. A recusa dos moradores de evacuar as casas a desinfetar; as reações à notificação e isolamento dos doentes, ao uso da vacina e à intervenção do poder público nos rituais fúnebres, os prejuízos econômicos de toda ordem desaguaram em revolta popular que obrigou Ricardo Jorge a fugir para Lisboa, onde assumiria posições de relevo em sua Escola Médica e em organismos centrais da saúde pública do regime monárquico. ${ }^{18}$

Está aí outro tema instigante para os estudiosos das relaçôes entre Brasil e Portugal: não apenas comparar os processos de instituição das medicinas pasteuriana e tropical nos dois países, como analisar as trocas de conhecimentos e as interações médico-sanitárias, sem perder de vista a moldura internacional que dava sentido a esses processos.

${ }^{15}$ AMARAL, Isabel - "A influência pasteuriana na obra de Ricardo Jorge e na emergência da medicina tropical". In AMARAL, Isabel; CARNEIRO, Ana; MOTA, Teresa Salomé; BORGES, Victor Machado, e DORIA, José Luis, 2010. Percursos da Saúde Pública nos séculos XIX e XX - a propósito de Ricardo Jorge. Lisboa: CELOM - FCT, pp. 135-144.

${ }^{16}$ CAMUS, Albert. 1971 - A peste. Rio de Janeiro: Editora Opera Mundi.

${ }^{17 A}$ esse respeito ver BENCHIMOL, Jaime Larry e TEIXEIRA, Luiz Antonio, 1993 - Cobras lagartos e outros bichos. Uma história comparada dos institutos Oswaldo Cruz e Butantan. Rio de Janeiro: Editora UFRJ/Casa de Oswaldo Cruz. TELAROLLI JR., Rodolpho 1996 - Poder e saúde: as epidemias e a formação dos serviços de Saúde em São Paulo. São Paulo: Editora da UNESP.

${ }^{18}$ RICON-FERRAZ, Amélia - "Páginas de história da medicina na obra de Ricardo de Almeida Jorge". In AMARAL, Isabel et al. - Perscursos da Saúde Pública ... pp. 15-25. 


\section{FEBRE AMARELA E IMIGRAÇÃO PORTUGUESA}

Na febre amarela, Ricardo Jorge encontrou matéria propícia à missão de induzir o "estreitamento espiritual das pátrias irmãs" ${ }^{19}$, em virtude da importância que tinha para as relaçôes entre América, Europa e África, como por representar ela importante fio na urdidura histórica das relações entre Portugal e sua ex-colônia. A doença tornara-se triste estigma do Rio de Janeiro, colhendo suas vítimas principalmente entre os imigrantes recém-chegados, especialmente os portugueses, que formavam a principal coletividade estrangeira da cidade. Na conferência proferida na Academia Brasileira de Letras lê-se passagem muito saborosa de Ricardo Jorge sobre o caudal humano oriundo do Porto, que ele qualificava como "o maior berço do Brasil moderno" 20 .

"O rapaz, que vinha descalço de sua aldeia, vestia a roupa nova de cotim, de jaqueta ao ombro, calçava chinelas de carnaz e cobria-se com chapéu braguês. A bagagem era a caixa de pinho, comprada na chamada Feira das Caixas (...). No surgidouro estreito do Douro (...) ancorava a (...) marinha veleira, mantida pelo tráfico de emigração e pelo comércio reinante com os portos do Brasil. (...) O pobre do emigrante empilhava-se à proa a roer a pedreneira da bolacha de bordo e a sonhar com a árvore das patacas, vendo-se já a apanhar sôfrego as pratas do chão, como lá na sua aldeia as bolotas caídas das carvalhas". ${ }^{21}$

Ricardo Jorge evocava então os lamentos das mães e mulheres dos embarcados e os tormentos que tornavam tão penosa a viagem até o Brasil, onde a febre amarela dizimava os emigrantes como "praga egípcia". ${ }^{22}$

Tais cenas encontram perfeito complemento nas páginas com que Luiz Edmundo pintou a cidade do Rio de Janeiro antes da campanha de Oswaldo Cruz e da remodelação urbana conduzida pelo prefeito Pereira Passos. Referindo-se ao cais Pharoux, fronteiro ao antigo Largo do Paço, no centro, escreveu:

"Por vezes (...) enche-se de homens que desembarcam, (...) sopesando canastras, baús, sacos, trouxas, pacotes, taramelando em voz alta (...). São imigrantes que chegam. Pobre e simpática gente (...). Trazem, todos, um ar medroso e parvo, os caróes secos e tisnados pelo sol, metidos em moldura ampla e circular dos enormes chapelóes de Braga (...). Olham o céu, com enternecimento, sentindo o azul, gozando a luz, beijando o ar! (...). Do bando enorme alguns sobram, ao fim de certo tempo. Caprichos da amarela que faz a ronda sinistra da cidade”. ${ }^{23}$

Os portugueses, que correspondiam a cerca de $1 / 3$ da população do Rio de Janeiro no começo do século XX, vinham majoritariamente do norte de Portugal, onde as pequenas explorações agrícolas aumentavam em número e diminuíam em tamanho, ocupando o Porto o primeiro lugar na origem dos emigrantes até a Primeira Guerra.

\footnotetext{
${ }^{19}$ JORGE, Ricardo - Brasil! Brasil! ... p. 82.

${ }^{20}$ Idem, ibidem, p. 19.

${ }^{21}$ Idem, ibidem, p. 19-20.

${ }^{22}$ Idem, ibidem, p. 21-22.

${ }^{23}$ EDMUNDO, Luís - O Rio de janeiro do meu tempo. Rio de Janeiro: Conquista, 1957, 5v., vol.1, p. 117-8.
} 
Em geral, o homem adulto partia com o objetivo de enriquecer e voltar para a aldeia, sem levar a família como faziam muitos italianos, espanhóis, alemães ou japoneses cuja emigração, direcionada às atividades rurais, era em larga medida subsidiada pela burguesia cafeeira, por estados e mesmo por companhias estrangeiras. ${ }^{24}$

Ricardo Jorge enfatizou o papel daqueles poucos que triunfavam da sorte e que regressavam ao norte de Portugal. Este 'brasileiro', com suas calças brancas, chapéu do Chile, cadeia de ouro e anel de brilhantes, "assomava e ascendia sobre o decair rápido das classes predominantes do velho regime. Aburguesaram fortemente o meio e regaram de libras a cidade e o campo. Bairros inteiros edificaram no Porto, cidade sua predileta. Eram seus o palacete urbano enfeitado com o brasão da fidalguia de fresca data (...). A igreja, a escola, o asilo, o hospício, o hospital, outros tantos marcos de sua benemerência dadivosa". 25

Quando o médico português esteve no Brasil, declinava já em Portugal o interesse pela emigração face à depressão econômica e à política colonial na África. O auge estende-se do último quartel do oitocentos até a Primeira Guerra Mundial. No Rio de Janeiro, tinham os imigrantes portugueses participação às vezes preponderante na mão de obra dos setores secundário e terciário. A mão de obra lusa era abundante nos serviços domésticos e entre caixeiros, vendedores ambulantes e outros empregados no comércio. Na obra de Luiz Edmundo colhem-se vívidos retratos desse universo: meninos vendendo jornais, o vassoureiro, o garrafeiro, o português que toca perus com vara comprida (Olha ôôô prú uuu da roda vôôô ôôa!). Cada qual contribuía com seus sons para a polifonia das ruas.

A insalubridade das habitaçōes para essa plebe urbana era há muito um traço marcante da vida carioca, aumentando ou arrefecendo a preocupação das autoridades em sincronia com as epidemias, pois as habitaçōes populares eram consideradas uma das principais produtoras dos miasmas morbígenos. E os portugueses sobressaíam entre os donos de cortiços, estalagens, casas de cômodos, hotéis e pensões. Sua influência nesse lado das relações entre capital e trabalho ia muito além: ocupavam posição de destaque na indústria, no comércio atacadista, no setor financeiro e na importação de vinhos, azeite, bacalhau e vários outros produtos ${ }^{26}$.

O fluxo migratório para o Brasil parece ter motivado reaçōes contraditórias em Portugal. Reduzia a formação do proletariado e do mercado de consumo, prejudicando assim o desenvolvimento industrial. Prejudicava também os latifúndios cerealíferos do sul que usavam o migrante do norte na época das colheitas. Por outro lado, as remessas de dinheiro dos emigrantes eram essenciais ao equilíbrio da balança de pagamentos, e o Brasil constituía importante mercado para os produtos lusos em boa medida graças à colônia portuguesa. Consta que, no começo dos anos 1890, o governo português tentou desencorajar a emigração, e que párocos foram instruídos a ler

${ }^{24}$ A esse respeito ver LOBO, Eulália Maria Lahmeyer - Imigração Portuguesa no Brasil. São Paulo: Ed. Hucitec, 2001. ISBN 8527105667. ROCHA TRINDADE, Maria Beatriz - "Refluxos culturais da emigração portuguesa para o Brasil”. Análise Social, vol. XXII, n. 90 (1986) pp. 139-156.

${ }^{25}$ JORGE, Ricardo - Brasil! Brasil! ... p. 23-24.

${ }^{26}$ LOBO, E. M. L. - Imigração Portuguesa no Brasil... p. 31-39, 44. Ver também

LOBO, Eulália Maria Lahmeyer - História do Rio de Janeiro: do capital comercial ao capital industrial e financeiro. Rio de Janeiro: IBMEC, 1978. 2v. 
nas igrejas listas de conterrâneos mortos no Brasil. Em 1923, o adido comercial no Brasil, Carvalho Neves, ainda argumentava que o comércio e as remessas de ouro não compensavam as perdas em "capital-homem". Em Portugal, baixava a taxa de natalidade, estava em crise a produção e as colônias ressentiam-se com a falta de mão de obra e capitais. ${ }^{27}$

Numa das conferências proferidas no Rio, Ricardo Jorge não economizou críticas aos economistas e higienistas da contraemigração. "Saber se há que dar de comer a tanta criança e se há lugar para tanto adulto, é o menor de seus cuidados. (...) Que fazer onde a produção-homem superabunda e a produção-trabalho escasseia? Fugir, emigrar, é um movimento biológico de defesa. Assim foi, é e continua a ser no Minho e alhures”. ${ }^{28}$

\section{A CRISE SANITÁRIA: ENQUADRAMENTOS CONCEITUAIS E AÇŌES PRÁTICAS}

As medidas econômico-financeiras adotadas após a proclamação da República brasileira, em 15 de novembro de 1889 , repercutiram dramaticamente sobre as condiçôes de vida da população do Rio de Janeiro ${ }^{29}$. A descontrolada expansão do meio-circulante, a queda da taxa de câmbio e a elevação das tarifas alfandegárias favoreceram o crescimento industrial, mas inflacionaram os preços dos gêneros de consumo. Esse quadro, agravado pela crise habitacional, explicam, em parte, a irrupção de violento sentimento antilusitano na capital brasileira, insuflado por grupos que disputavam a hegemonia no aparelho de Estado ${ }^{30}$. Por sua vez, as epidemias causaram devastaçôes jamais vistas nos anos 1890, exacerbando a má fama que tinha no mundo a capital brasileira. No relatório de 1891-1892 da Inspetoria Geral de Higiene Pública, leem-se palavras superlativas sobre a situação escritas por seu chefe, Bento Gonçalves Cruz, pai de Oswaldo Cruz: fazia-se tudo quanto era aconselhável para controlar as epidemias, mas em vão — visitas correcionais às habitações coletivas, aumento das acomodações nos hospitais de isolamento, distribuição pelas paróquias de médicos

${ }^{27}$ LOBO, E. M. L. - Imigração Portuguesa no Brasil... p. 19, 47-8. Ver também ROCHA TRINDADE, M. B. - "Refluxos culturais da emigração portuguesa para o Brasil... p. 145. E ainda SANTOS, Adailton Ferreira dos - "Conexões do Sanitarismo Moderno de Ricardo Jorge com o Brasil". In AMARAL, Isabel et al. - Perscursos da Saúde Pública ... p. 107-118.

${ }^{28}$ JORGE, Ricardo - Brasil! Brasil! ... p. 25-26.

${ }^{29}$ Entre 1872 e 1890, ela duplicou, passando de 274.972 para 522.651 habitantes. Em 1906, elevava-se a 811.444 habitantes. Era a única cidade do país com mais de 500 mil habitantes. Em 1900, o Porto tinha 169.955 habitantes, e Lisboa, 355.009 (só em 1960 o 'Concelho' de Lisboa alcançaria os 800 mil habitantes). Em 1872 e em 1890 , os estrangeiros representavam cerca de $30 \%$ da população carioca. Nesse último ano, havia 106.461 portugueses na cidade $-69 \%$ do total de imigrantes (77.954 homens e apenas 28.507 mulheres). Os imigrantes portugueses a seus descendentes diretos perfaziam, porém, 267.664 indivíduos em 1890, pouco mais da metade da população. Esses dados provém de LOBO, Eulália Maria Lahmeyer - Imigração Portuguesa no Brasil... p. 41-42. LOBO, E. M. L. - História do Rio de Janeiro... v. 2, p. 469-471. RODRIGUES, Teresa - "A dinâmica populacional da cidade do Porto em finais do século XIX”. Revista da Faculdade de Letras, p. 301-316 [texto datado de outubro de 1989]. Disponível em http://ler. letras.up.pt/uploads/ficheiros/2243.pdf. Também "Predefinição: População de Lisboa". Wikipédia, a enciclopédia livre. Disponível em http://pt.wikipedia.org/wiki/Predefini\%C3\%A7\%C3\%A3o:Popula\%C3\%A7\%C3\%A3o_de_Lisboa

${ }^{30}$ A esse respeito ver HAHNER, June E. - “Jacobinos versus Galegos. Urban Radicals versus Portuguese Immigrants in Rio de Janeiro in the 1890's". Journal of Interamerican Studies and World Affairs. Vol. 18, n. 2 (May 1976) pp. 125-54. LOBO, Eulália Maria Lahmeyer - Imigração Portuguesa no Brasil... pp. 17-18, 26-28. BENCHIMOL, Jaime L. - Pereira Passos: um Haussmann tropical. A renovação urbana do Rio de Janeiro no início do século XX. Rio de Janeiro: Secretaria Municipal de Cultura, Turismo e Esportes, Divisão de Editoração, 1990, pp. 184-187. 
para fiscalizar as condições de higiene etc. As medidas até então tidas como consensuais eram agora taxadas de inúteis ou perniciosas: "a alta administração do país, sem a orientação que só as autoridades científicas lhe podem fornecer, nada tem feito". ${ }^{31}$ Vejamos como se chegou a esse impasse, e como foi superado.

No verão de 1849-50, a primeira epidemia de febre amarela 'aportou' na capital do Império escravocrata governado por D. Pedro II, e desde então não a abandonou mais, fazendo frequentes incursōes em Lisboa e Porto. "Por muitos anos", - escreveu Ricardo Jorge —, "Portugal teve apenas uma obsessão profilática, a febre amarela, contra a qual a Saúde Pública estabeleceu uma organização de quarentena inquisitorial". ${ }^{32}$ Se em Portugal parece ter prevalecido a perspetiva contagionista, associada à importação de um mal 'estrangeiro', no Brasil o infeccionismo foi dominante. Aí os médicos que se ocupavam da higiene pública situavam as múltiplas causas da febre amarela no meio ambiente - tanto a 'natureza' daquelas latitudes tórridas, consideradas hostis à aclimatação do europeu, como o ambiente artificialmente criado pelo homem nas cidades oitocentistas. As 'constituições epidêmicas' de viés hipocrático que o presidente da Academia Imperial de Medicina refazia, quase todo ano, com o intuito de prever e prevenir as próximas epidemias eram como construçōes barrocas que ascendiam do movimento das populaçōes ao dos astros, interligando enorme quantidade de fatores morbígenos ${ }^{33}$.

"Ano de mangas, ano de febre amarela", diziam os cariocas, expressando em linguagem coloquial a relação que os médicos estabeleciam entre calor, umidade e epidemias. Como outras plantas, 'davam' sempre no verão, nas baixadas litorâneas, especialmente nas cidades portuárias, onde as matérias em putrefação constituíam humo ideal para a doença.

Em dezembro de 1879, o dr. Domingos José Freire, da Faculdade de Medicina do Rio de Janeiro, anunciou pelos jornais a descoberta do micróbio que julgava ser o causador da febre amarela. Desenvolveu uma vacina de largo uso a partir do Cryptococcus xanthogenicus. João Batista de Lacerda, por longo tempo diretor do Museu Nacional do Rio de Janeiro, incriminou o Fungus febris flavae. O médico cubano Carlos Juan Finlay propôs o Micrococcus tetragenus. George Sternberg, presidente da American Public Health Association, depois Surgeon General dos Estados Unidos, produziu em 1890 demolidor inquérito sobre essas e outras teorias, ao mesmo tempo em que buscava evidências em favor de um micróbio parecido com o do cólera. Robert Koch, seu descobridor (1884), enxergava analogias entre esta doença e a febre amarela, cujo principal sintoma, o vômito negro, localizava-se também no intestino. Bacilos então competiriam pela condição de agente causal da doença naqueles anos 1890 convulsionados pelo

${ }^{31}$ CRUZ, Bento Gonçalves. Relatório dos trabalhos da Inspetoria Geral de Higiene, de $1^{\circ}$ de janeiro de 1891 a maio de 1892, apresentado ao Sr. Dr. Fernando Lobo Leite Pereira, Ministro de Estado dos Negócios do Interior, pelo Dr. Bento Gonçalves Cruz, Inspetor Geral de Higiene. Rio de Janeiro: Imprensa Nacional, 1892, p. 65.

${ }^{32}$ JORGE, R. - La fièvre jaune et la campagne sanitaire a Rio de Janeiro ... p. 7. A esse respeito ver também ALVES, Jorge Fernandes - "Emigração e sanitarismo; Porto e Brasil no século XIX". Ler História. N.o 48 (2005), p. 141-156. Disponível em http://ler.letras.up.pt/uploads/ficheiros/artigo11231.pdf

${ }^{33}$ Sobre a febre amarela nesse no Brasil, nesse período, ver FRANCO, Odair - História da febre amarela no Brasil. Rio de Janeiro: Divisão de Cooperação e Divulgação [Ministério da Saúde] / Impressora Brasileira Ltda, 1969; BENCHIMOL, Jaime Larry - Dos micróbios aos mosquitos. Febre amarela e a revolução pasteuriana no Brasil. Rio de Janeiro: Editora Fiocruz/ Editora da UFRJ, 1999. 
colapso da escravidão, a enxurrada imigratória, as turbulências políticas decorrentes da proclamação da República e as econômicas associadas às oscilações do preço do café e a nossa revolução industrial 'retardatária'. ${ }^{34}$

O relativo consenso fundamentado na teoria miasmática a respeito do que se devia fazer para higienizar portos como o Rio de Janeiro deu lugar a candentes polêmicas sobre os elos a romper na cadeia da insalubridade urbana, até que um deslocamento radical na abordagem da febre amarela levou nova geração de bacteriologistas ao proscênio da saúde pública, sob a liderança de Oswaldo Cruz. As narrativas sobre essa virada privilegiam ora formulação da hipótese da transmissão pelo mosquito pelo cubano Carlos Juan Finlay, em 1880-81, ora sua demonstração, vinte anos depois, pela equipe norte-americana chefiada por Walter Reed (1900). ${ }^{35}$

A campanha que Oswaldo Cruz moveu contra a febre amarela como diretor-geral de Saúde Pública (DGSP), no governo de Rodrigues Alves (1902-1906), consistiu em impedir a contaminação dos mosquitos pelos amarelentos infetantes; a infeção das pessoas receptíveis pelos mosquitos contaminados e a permanência dos casos esporádicos nos intervalos epidêmicos. Baseava-se na ideia de que o micróbio da febre amarela, ainda desconhecido, tinha somente dois hospedeiros: o homem e uma única espécie de mosquito, o Stegomyia fasciata (atual Aedes aegypti). ${ }^{36}$ Em fins de 1905, Oswaldo Cruz iniciou a inspeção de outros portos brasileiros, tendo em mira açôes de maior alcance contra a febre amarela (que não pôde realizar). Em Manaus, capital do Amazonas, conheceu Harold Howard Shearme Wolferstan Thomas, pesquisador da Liverpool School of Tropical Medicine. Chegara há pouco com a missão de investigar aquela doença. Os quadros da instituição britânica mal davam conta das expediçōes à África, Índia e ao Oriente, tendo em mira, a princípio, a malária, depois a doença do sono e outras tripanossomíases. Foi justamente nesse terreno que Thomas ganhou projeção. Em 1903, demonstrou que um composto orgânico arsenical, o atoxyl, parecia ser eficiente no tratamento das tripanossomíases. Ehrlich visitou esse laboratório, e suas próprias investigaçôes com o atoxyl levá-lo-iam, em 1910, ao Salvarsan, primeiro remédio eficaz contra a sífilis ${ }^{37}$.

\footnotetext{
${ }^{34}$ BENCHIMOL, J. L. - Dos micróbios aos mosquitos... Também BENCHIMOL, J. L. - "O Brasil e a medicina tropical dos anos 1880 até a Primeira Guerra Mundial”. In Amaral, Isabel et al. - Percursos da Saúde Pública nos séculos XIX e XX... pp. 119-134.

${ }^{35}$ STEPAN, Nancy - "The interplay between socioeconomic factors and medical science: yellow fever research, Cuba and the United States”. Social Studies of Science. London. Vol. 8 (1978) pp. 397-423. DELAPORTE, François - Histoire de la fièvre jaune. Paris: Payot, 1989.

${ }^{36}$ Quanto à varíola, bastaria vacinar toda a população. A peste bubônica seria detida pelo extermínio dos ratos, por medidas de cunho urbanístico e pelo uso do soro e da vacina fabricados nos institutos criados nas fazendas de Manguinhos e Butantan. Aquelas medidas puseram em conflito uma multidão de atores e acontecimentos. A peste foi subjugada, a febre amarela desapareceu do Rio de Janeiro, mas só momentaneamente; a Revolta da Vacina neutralizou a ofensiva contra a varíola que, em 1908, matou 6.400 dos 800 mil habitantes da capital brasileira. A esse respeito (e sobre a literatura a esse respeito) ver BENCHIMOL, Jaime Larry - "Reforma urbana e revolta da vacina na cidade do Rio de Janeiro". In FERREIRA, Jorge; NEVES, Lucilia de Almeida - O Brasil republicano. Economia e sociedade, poder e política, cultura e representações (4 vols.), vol. 1: O tempo do liberalismo excludente - Da proclamação da República à Revolução de 1930. Rio de Janeiro: Editora Civilização Brasileira, 2003, pp. 231-86.

${ }^{37}$ RIETHMILLER, Steven - "Erlich, Bertheim and Atoxyl: the origins of modern chemotherapy”. Bulletin for the History of Chemistry. N. 23 (1999) pp. 28-33.
} 
Não deixa de ser intrigante a decisão de enviar à Amazônia quadro envolvido nas pesquisas sobre tripanossomíases africanas, quando estavam elas no auge. Explico então. A comissão Reed deixara no ar a hipótese de que o agente da febre amarela fosse um 'vírus filtrável', mas as analogias com a malária levaram muitos investigadores à suposição de que era um protozoário, hipótese defendida pelo próprio Finlay. Em 1905, Fritz Richard Schaudinn, em colaboração de Erich Hoffmann, anunciou a descoberta do agente da sífilis, o Spirochaeta pallida (Treponema pallidum). Os Spirochaetae eram vistos à época ora como bactérias, ora como protozoários. Às vésperas desta descoberta (1904), Schaudinn apresentou resultados de experimentos com a coruja Athene noctua, em que encontrara formas cujos ciclos de vida podiam incluir mosquitos como hospedeiros intermediários. Aí os Spirochaetae tornavam-se tão pequenos que atravessavam os mais finos aparelhos de filtragem de bactérias. Ao apresentar as metas subsequentes de suas pesquisas declarou: "Minhas observações sobre a diminuição dos espiroquetas durante sua reprodução levam-me a supor que também possam ser os agentes patogênicos na febre amarela". ${ }^{38}$

Foi essa a premissa que norteou as pesquisas de Hans Erich Moritz Otto e Rudolf Otto Neumann, do Instituto de Doenças Marítimas e Tropicais de Hamburgo, quando estiveram no Rio de Janeiro, em 1905, no auge da campanha de Oswaldo Cruz. ${ }^{39} \mathrm{O}$ norte-americano Arthur Marston Stimson foi o primeiro a descrever um espiroqueta ( $S$. interrogans, 1907) nos tecidos de uma vítima da febre amarela. ${ }^{40}$ A hipótese de Schaudinn ganhou muito terreno durante a Primeira Guerra Mundial, quando, no Japão, Inada e colaboradores incriminaram o S. icterohaemorrhagiae como agente de outra doença caracterizada por icterícia e hemorragias, a Doença de Weil, que conhecemos hoje como leptospirose. O curto-circuito com a febre amarela foi 'fechado' em 1918, em Guayaquil, no Equador, por Hideyo Noguchi, bacteriologista do Instituto Rockefeller. Para acomodar o seu espiroqueta e o de Inada, criou novo gênero, Leptospira, válido ainda hoje. $\mathrm{O}$ da febre amarela seria filtrável, mas apresentava formas visíveis no microscópio de campo escuro. As experiências de transmissão a animais, sobretudo ao porquinho-da-índia, revelavam o parentesco com o agente da icterícia hemorrágica.

Ao eclodir a Primeira Guerra, a Fundação Rockefeller havia já decidido empreender a erradicação mundial da febre amarela com base na chamada teoria dos focos-chave: eliminar-se-iam os locais em que procriava o Stegomyia fasciata (Aedes aegypti), considerado o único vetor, mas somente em alguns centros endêmicos — as sementeiras que propagavam epidemias a outras aglomerações do litoral e do interior. Quando afinal começou a campanha em Guayaquil, em novembro de 1918, todos os aspectos

${ }^{38}$ SCHAUDINN, Fritz - "Generations und Wirtswechsel bei Trypanosoma und Spirochaete". Arbeiten aus dem Kaiserl. Gesundheitsamte. Vol. 20, n. 3 (1904), pp. 566-573 (trecho citado p. 571).

${ }^{39}$ Sobre esta missão e a do Instituto Pasteur, que por tempo mais longo esteve no Rio de Janeiro, ver LÖWY, Ilana - "La mission de l'Institut Pasteur à Rio de Janeiro: 1901-1905". In MORANGE, M. - L'Institut Pasteur, contribution à son histoire. Paris: La Découverte, p.195-279, 1991. BENCHIMOL, Jaime Larry; SÁ, Magali Romero. "Insetos, humanos e doenças: Adolpho Lutz e a medicina tropical". In BENCHIMOL, J. L.; SÁ, M. R. (org.) - Adolpho Lutz, Obra Completa, vol. II, livro 1: Febre amarela, malária \& protozoologia. Yellow Fever, Malaria \& Protozoology. Rio de Janeiro: Editora Fiocruz, pp. 43-244, 2005.

${ }^{40}$ STIMSON, A. M. - "Note on an organism found in yellow-fever tissue". Public Health Reports; Vol. 22, n.18 (1907) p. 541. 
da febre amarela pareciam cientificamente equacionados ${ }^{41}$. E já em 1922, na avaliação da Junta Sanitária Internacional da Fundação Rockefeller, a costa oriental da América do Sul achava-se praticamente livre da doença. O governo brasileiro autorizou então (1.5.1923) o recém-criado Departamento Nacional de Saúde Pública (DNSP) a aceitar a cooperação da Rockefeller no combate à doença. As negociações tiveram como combustível uma epidemia no Estado do Ceará, que o historiador pode acompanhar a partir do laboratório de Noguchi, em Nova York, já que os atores nela envolvidos recorreram fartamente ao soro e à vacina lá produzidos. ${ }^{42}$

A partir de 1927, Noguchi tornou-se alvo de laboratórios que manejavam bem o ferramental da imunologia. Na Harvard School of Tropical Medicine, por exemplo, Max Theiler e Andrew Watson Sellards verificaram que eram idênticas as reações do L. icteroides e do L. icterohemorrhagiae. Embora os biógrafos de Noguchi deem como liquidada a fatura com essas publicações, elas deixavam em aberto um programa complexo de pesquisas. Se o L. icteroides não era o causador da febre amarela, casos da icterícia infeciosa (leptospirose) vinham sendo diagnosticados como tal - e não é difícil supor o impacto que essa hipótese teve sobre os quadros da Rockefeller que combatiam a febre amarela nos países americanos, baseando-se em Noguchi para estabelecer diagnósticos imprecisos, muito frequentes. Por outro lado, alguns especialistas admitiam a hipótese de que a icterícia infeciosa era a febre amarela das zonas temperadas. No Office International d'Hygiène Publique, em novembro de 1927, Ricardo Jorge contestou esse ponto de vista: "Eu vi uma e outra pessoalmente em Portugal. Os mesmos sintomas aparecem bem no começo mas diferenças marcadas existem em seguida, e ademais a epidemiologia é absolutamente diferente". ${ }^{43}$

Essas e outras indefinições requeriam a repetição das experiências com cepas novas e antigas daqueles Leptospira; e mais experimentos com mosquitos. Ademais, segundo Theiler e Sellards, era preciso "refletir seriamente" sobre o ponto de vista o ciclo do agente da febre amarela estava confinado ao homem e ao mosquito. ${ }^{44}$

\section{AméricA, África e febre AMARELA: o DEbate SOBRe AS ORIGENS}

Em junho de 1920, Gorgas assumiu a chefia de uma comissão incumbida de determinar se havia febre amarela na costa ocidental da África e se eram viáveis lá as medidas

\footnotetext{
${ }^{41}$ CUETO, Marcos (org). - Missionaries of science: the Rockefeller Foundation \& Latin America. Bloomington: Indiana University Press, 1994.

${ }^{42}$ Sobre a campanha contra a febre amarela da Fundação Rockefeller ver LÖWY, Ilana - Mosquitos e modernidade: a febre amarela no Brasil entre ciência e política. Rio de Janeiro: Editora Fiocruz, 2006. Especificamente sobre o papel de Noguchi e as iniciativas contra a febre amarela na América e África ver BENCHIMOL, Jaime Larry - "Hideyo Noguchi e a Fundação Rockefeller na campanha internacional contra a febre amarela (1918-1928)". In BASTOS, Cristiana; BARRETO, Renilda (orgs). - Impérios, centros e províncias: a circulação do conhecimento médico. Lisboa: Imprensa de Ciências Sociais, série digital, pp. 199- 338, 2011. Disponível em https:// www.imprensa.ics.ul.pt/download/books/bastos_barreto/bastos_e_barreto_circulacao.pdf .

${ }^{43}$ JORGE, Ricardo - Fièvre Jaune... p. 4.

${ }^{44}$ SELLARDS, Andrew Watson - "The Pfeiffer reaction with Leptospira in Yellow Fever”. American Journal of Tropical Medicine. S1-7, n. 2 (1927) p. 71-95.
} 
adotadas na América. Ele faleceu em Londres (4.6) e a liderança da expedição passou a respeitado sanitarista cubano, Juan Guiteras Gener, colaborador de Finlay. As investigaçôes concentraram-se no litoral entre Lagos, antigo entreposto negreiro do golfo da Guiné, e Dakar, capital do Senegal, então colônia francesa, pois esses portos abrigavam maior população branca, considerada mais suscetível à febre amarela, e possuíam laboratórios e hospitais.

Foram negativos os estudos sobre ambas as Leptospira e as tentativas de identificar clinicamente casos autênticos da febre amarela nas regiôes visitadas. "Fenômeno curioso", escreveu Guiteras, "as três coisas que mais pensava eu encontrar na África brilharam por sua ausência: nem febre amarela, nem calor, nem mosquitos”. ${ }^{45}$

Desde o inquérito feito por comissão britânica chefiada por Rupert Boyce, nos anos $1910,{ }^{46}$ acreditavam alguns que havia uma forma tênue da doença endêmica entre os nativos, constituindo eles um reservatório para o "vírus" que, de tempos em tempos, tornava-se agressivo para os europeus. Crença arraigada entre os médicos da época era a resistência dos negros à febre amarela. Haveria uma resistência natural de raça? - indagava Guiteras, lembrando ele que nas epidemias do sul dos Estados Unidos, o negro era "enfermeiro, assistente e coveiro dos brancos que feneciam”. As histórias que ouviu o médico cubano na África e suas inferências estatísticas levaram-no a correlacionar a falta do "elemento branco" à pouca extensão da febre amarela, supondo até que pudesse estar em extinção lá. ${ }^{47}$

Ricardo Jorge envolveu-se com entusiasmo nessa discussão. Para ele, eram escassas as informaçōes sobre a doença na África porque os médicos europeus tinham "escrúpulos de diagnóstico" ou eram proibidos pelas autoridades coloniais de chamar atenção sobre a febre amarela. ${ }^{48}$

Aquelas indefinições estavam interligadas a uma questão de natureza histórica que muito seduzia o erudito médico e escritor português. O parecer da comissão Guiteras apoiava-se na teoria de que a febre amarela era originária da América. A África nunca apresentara centros irradiadores do porte de Havana, Rio de Janeiro ou Yucatán. Ricardo Jorge endossou este ponto de vista. Ao desembarcar em São Domingos, Colombo teria encontrado já a doença endêmica entre os indígenas das Antilhas, das costas da Venezuela, Colômbia e México. Daí se propagou pelo litoral do Atlântico e do Pacífico. Em fins de 1685, irrompeu em Pernambuco, e daquela capitania a febre amarela migrou para a Bahia. O médico João Ferreira da Rosa escreveu a esse respeito o Tratado da Constituição Pestilencial de Pernambuco (1694), um dos primeiros documentos da medicina colonial lusa, e, parece, a primeira descrição feita por médico da febre amarela nas Américas ${ }^{49}$. E Miguel Dias Pimenta, autor de Noticia do que He o

${ }^{45}$ GUITERAS GENER, Juan - "Expedición al África y estudios de fiebre amarilla”. Anales de la Academia de Ciencias Médicas, Físicas e Naturales de la Habana. Vol. 57 (1921) pp. 265-287 (trecho citado, p. 272).

${ }^{46}$ BOYCE, Sir Rupert William - "The History of Yellow Fever in West Africa”. The British Medical Journal, Vol. 1, n. 2614 (4.2.1911) pp. 301-306.

${ }^{47}$ GUITERAS GENER, Juan - “Expedición al África ... pp. 278, 280.

${ }^{48}$ JORGE, Ricardo - Fièvre Jaune... p. 1.

${ }^{49}$ JORGE, Ricardo - La fièvre jaune et la campagne sanitaire a Rio de Janeiro... p. 5-6. Odair Franco comentou pequeno extrato desse livro em MINISTÉRIO DA SAÚDE, FUNDAÇÃO SERVIÇOS DE SAÚDE PÚBLICA - A febre amarela no século XVII no Brasil. Extratos do Tratado Unico da constituiçam pestilencial de Pernambuco por 
achaque do Bicho, de 1707, forneceu dados sobre a epidemia de Pernambuco: num mês (28.11.1685 a 10.1. 1686), levara ao túmulo, em Recife e em Santo Antônio, "600 brancos, uma dúzia mais ou menos de mulatos, poucos negros, poucas mulheres e número ainda menor de crianças'. ${ }^{50}$ Depois disso, o mal deixou de atacar os nativos, mas durante oito anos não poupou os recém-chegados. Ferreira da Rosa calculou em 2.000 as vítimas ao longo desses anos, e atribuiu a origem da epidemia a barris de carne trazidos de São Tomé, opinião que Ricardo Jorge julgou "inverossímil" (ibidem). Para ele, a África teria sido contaminada por navios negreiros, constituindo evidência disso a "epidemização" do Senegal e das ilhas de Cabo Verde em 1763. Nesse mesmo século, a febre amarela invadiu Espanha e Portugal. Viria a causar grandes estragos em portos de mar europeus, ao passo que na África prevaleceriam epidemias silenciosas, uma das quais grassaria por dez anos em Angola, a partir de 1860. Seria o golfo da Guiné um centro endêmico similar ao do México? - especula Ricardo Jorge. ${ }^{51}$

No Brasil perderam-se os traços da febre amarela até meados do século XIX, "mas o fogo incubava sempre," - escreveu ele - "lançando por vezes chispas que iam atear incêndios em outras partes". ${ }^{52}$ Navios que partiam infetados de Pernambuco apresentavam epidemias a bordo, até que uma irrompeu em Lisboa, em 1723, matando seis mil pessoas em 3 meses, segundo relato de Simão Felix da Cunha. ${ }^{53}$ Desse ano a 1857, quando a capital portuguesa foi palco de outra epidemia grave, a febre amarela apareceu por diversas vezes em Portugal. ${ }^{54}$

No século XIX, com maior ou menor intensidade, ela grassou de Nova York a Buenos Aires, nas vertentes do Atlântico e do Pacífico, transformando duas cidades -- Havana e Rio de Janeiro -- em "vulcōes infeciosos" permanentes. Apesar do domínio geográfico

Joam Ferreira da Rosa, 1694, e da História da febre amarela no Brasil, de Dr. Odair Franco, 1969. Rio de Janeiro: Editora Pensamentpo S/A, 1971. Um exemplar do livro de Ferreira da Rosa foi trazido para o Brasil por iniciativa do dr. José Maria da Cruz Jobim, que se interessou pela doença quando ela irrompeu pela primeira vez na capital brasileira, no verão de 1849-1850 (RIBEIRO, Lourival - O barāo do Lavradio e a higiene no Rio de Janeiro. Belo Horizonte: Editora Itatiaia Ltda, p. 88, 1992). Encontra-se em http://www.archive.org/details/trattadounicodac00rosa a edição original de ROSA, Joam Ferreira da - Trattado único da constituiçam pestilencial de Pernambuco offerecido a El Rey N. S. por ser servido ordenar por seu Governador aos Médicos da America, que assistem aonde há este contagio, que o compusessem para se conferirem pelos Coripheos da Medicina aos dictames com que He trattada esta pestilencial febre. Lisboa: Officina de Miguel Manescal, 1694.

${ }^{50}$ JORGE, Ricardo - La fièvre jaune et la campagne sanitaire a Rio de Janeiro... p. 6. Em em WWW: <URL: http://www.archive.org/details/noticiasdoqueheo00pime> encontra-se edição original de PIMENTA, Miguel Dias - Noticias do que He o achaque do bicho, diffiniçam do seu crestamento, fubimento corrupção, finaes \& cura até, o quinto grão, ou intenção delle, suas diferenças, \& complicações, com que se ajunta. Lisboa: Officina de Miguel Menescal, 1707.

${ }^{51}$ JORGE, R. - Fièvre Jaune... p. 1, 5, 7.

${ }^{52}$ JORGE, R. - La fièvre jaune et la campagne sanitaire a Rio de Janeiro... p. 6.

${ }^{53}$ Idem, ibidem. Ricardo Jorge cita aí CUNHA, Simão Felix da - Discurso e observações apollineas sobre as doenças que houve na cidade de Lisboa occidental e oriental, o outubro de 1723. Lisboa, José Antonio da Silva 1726. Em SILVA, Innocencio Francisco da - Diccionario Bibliographico Portuguez. Lisboa: Imprensa Nacional, 1862, t. VII, p. 277, consta que este "raro e esquecido livrinho" foi redescoberto pelos médicos portugueses quando grassou a febre amarela em Lisboa, em 1857. "Com efeito, Simão Felix da Cunha parece ter sido o segundo prático português que observara e tratara aquela terrível enfermidade (...). O primeiro, ainda no século anterior, foi sem dúvida João Ferreira da Rosa”. Lê-se aí que as Observações apollineas... foram reproduzidas na Gazeta medica de Lisboa, a partir do n. ${ }^{\circ} 114$, de 16.9.1857.

${ }^{54}$ JORGE, R. - Fièvre Jaune... p. 3. 
mais restrito, a febre amarela formou com a peste bubônica e o cólera a tríade soberana da higiene internacional. ${ }^{55}$

No começo dos anos 1920, Henry Rose Carter, integrante da comissão que mapeara os focos-chave da América, iniciou pesquisas que resultaram em livro póstumo (1931) em que discutia as origens da febre amarela. ${ }^{56}$ Uma de suas fontes, Emilio Goeldi, fora diretor do Museu Paraense de História Natural e Etnografia. Como outros precursores da entomologia médica, Goeldi debruçou-se sobre os hábitos e a biologia do mosquito que acabava de ser associado à transmissão da doença. Goeldi e seus pares endossaram o mapa de distribuição do Stegomyia fasciata produzido por Theobald, do Museu Britânico, mas só o zóologo suíço, que eu saiba, aventurou-se a especular sobre a origem daquela espécie. Na contracorrente da teoria dominante, julgou-a de origem africana. Teria migrado para a América em navios negreiros como outros parasitas de humanos - o 'bicho do pé' e a filaria, por exemplo. ${ }^{57}$

Verificaram aqueles médicos-entomologistas que os ovos do Stegomyia fasciata, capazes de resistir a condições adversas e eclodir a longas distâncias. Para propagar a febre amarela, o mosquito dependia de centros populosos no litoral. Pois na costa atlântica, segundo Goeldi, em nenhum lugar ter-se-iam condensado os indígenas americanos à época da chegada dos europeus, ao passo que as populações africanas cedo formaram aglomerações populosas.

Baseando-se nas pesquisas de Carter e, indiretamente, nas de Goeldi, já em 1924 Joseph Hill White, diretor da campanha contra a febre amarela no Brasil, endossava a ideia de que os espanhóis a tinham trazido da África para as Antilhas. ${ }^{58}$

Em 1925, uma segunda comissão da Fundação Rockefeller, chefiada por Henry Beeuwkes, foi enviada para Lagos, capital da Nigéria, então colônia britânica. Durante dois anos, a comissão examinou muitos casos, investigou a bacteriologia e os possíveis vetores da doença, e não conseguiu isolar o microrganismo de Noguchi. Isso fortaleceu a suspeita de que a febre amarela africana era diferente da americana. No Office International d'Hygiène Publique, em maio de 1928, Ricardo Jorge manifestou-se sobre aquela questão, julgando mais provável que a espiroqueta de Noguchi não fosse o agente causal da febre amarela. ${ }^{59} \mathrm{Na}$ mesma sessão, Carlos Chagas pediu a seus colegas que não tomassem ainda posição definitiva a esse respeito. ${ }^{60}$ Havia então forte contraste entre a situação da doença num e noutro lado do Atlântico. Se na

${ }^{55}$ JORGE, R. - La fièvre jaune et la campagne sanitaire a Rio de Janeiro... p. 7.

${ }^{56}$ CARTER, Henry Rose 1931 - Yellow fever: an epidemiological and historical study of its place and origin. Baltimore: Williams \& Wilkins.

${ }^{57}$ GOELDI, Emilio 1905 - Os mosquitos no Pará. Reuniāo de quatro trabalhos sobre os mosquitos indigenas, principalmente as especies que molestam os homens. Pará (Brazil): Estabelecimento Graphico C. Wiegandt, p. 75. A hipótese de Goeldi foi desenvolvida também por FREITAS, Octavio de - Doenças africanas no Brasil. São Paulo: Companhia Editora Nacional, 1935. Sobre os estudos iniciais sobre o transmissor da febre amarela ver BENCHIMOL, Jaime Larry - "Mosquitos, doenças e ambientes em perspetiva histórica". In FERREIRA, Marieta de Moraes (org.) 2011 - Anais do XXVI simpósio nacional da ANPUH - Associação Nacional de História. São Paulo: ANPUH-SP. Disponível em http://www.snh2011.anpuh.org/resources/anais/14/1311956562_ARQUIVO_JaimeBenchimolfinal.pdf

${ }^{58}$ WHITE, Joseph Hill - "Epidemiologia da febre amarela". A Folha Medica, ano V, n.17 (1.9.1924) p. 193-197.

${ }^{59}$ JORGE, R. - Fièvre Jaune... p. 5-6.

${ }^{60} \mathrm{Idem}$, ibidem. 
África patinavam os sanitaristas, na América parecia quase extinta a febre amarela. E Frederick Russel, o diretor da Divisão Sanitária Internacional da Fundação Rockefeller considerava tão promissoras as perspetivas no Brasil que autorizara o início da desmobilização de homens e equipamentos, e a transferência de alguns quadros para a África.

Aí, em junho de 1927, segundo Beeuwkes, o chefe da West África Yellow Fever Commission, a situação estava no seguinte pé: "Não conseguimos isolar a Leptospira icteroides ... um animal definitivamente suscetível não foi encontrado ainda, e os testes de Pfeiffer, usando várias cepas de Leptospira icteroides e Leptospira icterohaemorrhagiae, têm sido em geral negativos. A cobaia é o único animal de que fizemos uso nesses testes". ${ }^{61}$

Uma epidemia na Costa do Ouro levou à criação de laboratório filial em Acra (Gana, também colônia britânica) onde se instalou Johannes Bauer, recém-chegado do laboratório de Noguchi. Em maio de 1927, Beeuwkes comprou em Hamburgo macacos da Índia (rhesus e crown monkeys) ${ }^{62}$ e do Brasil (saguis) e zarpou para Lagos com Adrian Stokes, da Universidade de Dublin, ex-integrante da primeira Comissão enviada pela Rockefeller à África e um dos primeiros na Europa a verificar as descobertas de Inada. Quando atracaram em Acra, Stokes desembarcou para ajudar Bauer no laboratório filial ao de Lagos. Em localidade próxima - Kpeve, região do lago Volta - tinham obtido espécimes de sangue de pacientes com infeções leves, um dos quais era um africano de 28 anos de idade chamado Asibi (cito-o porque a trajetória da cepa de vírus dele extraída nos leva a vacinas hoje em uso contra a febre amarela ${ }^{63}$ ). Dias depois, macacos e cobaias foram inoculados com sangue de grupos de casos humanos, pois era difícil saber se qualquer um, individualmente, era com certeza febre amarela. Alguns macacos morreram e as autópsias mostraram alteraçōes sugestivas da doença.

Tudo o que sabiam então era que macacos indianos pareciam ser mais suscetíveis do que cobaias e outros animais. São abundantes e tumultuários os detalhes dessa virada decisiva. Em relato de 14 de julho de 1927, o foco estreita: sinais muito sugestivos apresentara um rhesus inoculado com material oriundo de Asibi. Havia porém muitas incertezas em ambos os lados da equação. Faltavam ferramentas seguras para o diagnóstico da febre amarela humana, sobretudo os casos frustros ou tênues, e conheciam mal a incubação do vírus nos macacos, sobre cuja histologia normal e patológica quase nada sabiam. ${ }^{64}$ Daquele universo caótico resultavam pouquíssimas cepas seguras, e como conservá-las? Os macacos indianos eram caros, difíceis de obter e sujeitos a enfermidades arrasadoras. A infeção de mosquitos e a reprodução da doença por seu intermédio oferecia perspetivas promissoras, mas aí também a comissão esbarrava

${ }^{61}$ BEEUWKES, Henry - carta ao dr. Lasnet, inspetor-geral dos Services Sanitaires et Médicaux em 8.6.1927. Rockefeller Archive Center, Coll. RF, RG 5, IHB, S-1, SS-2 - Bx 306 - F-3886. BEEUWKES, Henry - carta ao dr. Lasnet, inspetor-geral dos Services Sanitaires et Médicaux em 8.6.1927. Rockefeller Archive Center, Coll. RF, RG 5, IHB, S-1, SS-2 - Bx 306 - F-3886. O desenrolar desta história é relatada em detalhes em BENCHIMOL, J. L. - "Hideyo Noguchi e a Fundação Rockefeller na campanha internacional contra a febre amarela (1918-1928)"...

${ }^{62}$ Macaco coroado (Macaca radiata), natural da Ásia, espécie endêmica na Índia. Uso crown monkey porque à época os pesquisadores da Rockefeller não o tinham classificado ainda corretamente.

${ }^{63}$ BENCHIMOL, Jaime Larry (coord.) - Febre amarela: a doença e a vacina, uma história inacabada. Rio de Janeiro: Editora Fiocruz, 2001.

${ }^{64}$ BEEUWKES, Henry - Carta a Sawyer, 10.8.1927. Rockefeller Archive Center, Coll. RF, RG 5, IHB, S-1, SS-2 - Bx 306- F-3886. 
num mundo de problemas novos. Estava às voltas outra vez com aquela categoria de microrganismos invisíveis aos microscópios mais possantes, que só se revelava através das lesões produzidas no movimento incessante de organismo a organismo.

Os americanos precisavam de um caso humano indiscutível produzido pelo vírus que passavam de macaco a macaco e a mosquitos, para ter a evidência definitiva de que era o agente da febre amarela. A experimentação humana ocorreu em Lagos, mas de forma involuntária e dramática: Adrian Stokes foi hospitalizado em 15 de setembro de 1927 e faleceu quatro dias depois, o que acelerou tremendamente o giro daqueles trabalhos. ${ }^{65}$

Nota preliminar de Stokes, Bauer e Hudson, concluída no final daquele ano, foi publicada no ano seguinte. Artigo mais completo demonstrou que a infeção era facilmente transmitida de macaco a macaco, assim como de homem a macaco por meio da injeção de sangue ou da picada de Aedes aegypti. ${ }^{66}$ Bauer, por sua vez, relatou a transmissão da febre amarela por duas outras espécies do gênero Aedes, A. luteocephalus e $A$. apicoannulatus, e também pelo Eretmapodites chrysogaster. ${ }^{67}$

Em novembro de 1927, Noguchi desembarcou em Acra e começou a trabalhar independentemente do pessoal de Lagos. Suas observações foram por um tempo coincidentes com as do laboratório rival, mas de seu âmago começou a extrair uma descoberta inteiramente discrepante que o levaria, caso fosse comprovada, à demonstração de que a febre amarela americana e africana eram, de fato, doenças diferentes, duas espécies afins como o Leptospira icteroides e o icterohaemorrhagiae. Ele já preparava o regresso a Nova York, com grande quantidade de material para prosseguir lá os estudos, quando foi hospitalizado. Faleceu em 21 de maio de 1928, aos 51 anos de idade. Durante a agonia de Noguchi, William Alexander Young, diretor do hospital britânico em Acra, fez o possível para preservar evidências de seu trabalho. Oito dias depois, morria também de febre amarela. ${ }^{68}$

\section{O REGRESSO DA FEBRE AMARELA À CAPITAL BRASILEIRA E SEUS DESDOBRAMENTOS}

Pois nesse fatídico maio de 1928, no Rio de Janeiro, teve início a epidemia que representou profundo golpe na estratégia da Rockefeller. "Contava-se já com ... a extinção definitiva da doença” - escreveu Ricardo Jorge; — "Pois bem, a morimbunda ia se levantar ainda, na África e no Brasil, e causar preocupações aos higienistas". ${ }^{69}$

${ }^{65}$ Detalhes a esse respeito em BENCHIMOL, J. L. - "Hideyo Noguchi e a Fundação Rockefeller na campanha internacional contra a febre amarela (1918-1928)"...

${ }^{66}$ STOKES, Adrian; BAUER, Johannes H.; HUDSON, N. Paul - "Experimental Transmission of yellow fever to laboratory animals”. American Journal of Tropical Medicine, 8 (1928) p; 103-164. STOKES, Adrian, Johannes H. BAUERT, e N. Paul HUDSON - "Transmission of yellow fever to Macacus rhesus, preliminary note". Journal of the American Medical Association, 90 (1928) p. 253-254.

${ }^{67}$ BAUER, Johannes H. - "Transmission of yellow fever by mosquitoes other than Aedes aegypti". American Journal of Tropical Medicine, 8 (1928) p. 261-282.

${ }^{68}$ Detalhes a esse respeito em BENCHIMOL, J. L. - "Hideyo Noguchi e a Fundação Rockefeller na campanha internacional contra a febre amarela (1918-1928)"... A melhor biografia sobre Noguchi é ainda PLESSET, Isabel R. - Noguchi and his patrons. New Jersey: Associated University Press, 1980.

${ }^{69}$ JORGE, R. - Fièvre Jaune... p. 9. 
$\mathrm{Na}$ capital brasileira, obedecendo a seu conhecido regime sazonal, a curva epidêmica ascendeu até junho de 1928 e caiu. Voltou a ascender no verão seguinte, em janeiro de 1929, e a descida foi mais rápida por força das açôes sanitárias, o que viabilizou os festejos do centenário da Academia de Medicina, em junho. A Ricardo Jorge e aos médicos estrangeiros, Clementino Fraga declarou: "Pago 30.000 francos a aquele que me apresentar um mosquito apanhado na cidade propriamente dita" ${ }^{70}$

Nela encenava-se uma peça humorística sobre os mata-mosquitos, e fazia sucesso um disco de gramofone com zombarias contra eles. ${ }^{71} \mathrm{~A}$ oposição atacava o governo de Washington Luiz, comparando o tempo todo seu diretor de saúde pública, Clementino Fraga, com o 'saneador do Rio de Janeiro', Oswaldo Cruz. Mas este combatera a doença no centro de uma cidade com cerca de oitocentos mil habitantes. Agora, eram mais de um milhão e meio, grande parte dos quais nos subúrbios, teatro das principais ações sanitárias. Fraga reuniu um exército de mais de 7 mil homens (o de Oswaldo Cruz ia pouco além de mil). Pela primeira vez, grandes empresas, associações de classe e outros componentes da sociedade civil colaboraram ativamente no esforço de mobilizar a população contra os alvos que a saúde pública desejava atingir. A Fox Filmes e a Light, e empresa de energia elétrica, produziram aquele filme enviado a Ricardo Jorge, demonstrando as providências que os moradores deviam adotar ou apoiar. ${ }^{72}$

Um fator agravante da crise era o despreparo dos médicos. Veteranos de antigas epidemias foram mobilizados para instruir os mais jovens, que nunca tinham visto febre amarela. Fã do método oswaldiano, o médico português passou em revista batalhōes de guardas sanitários e assistiu a operações inseticidas com duplo alvo: as larvas e os insetos adultos. Para o "expurgo" destes, recobriam-se os tetos dos prédios com vastos tecidos e calafetavam-se janelas e portas com fitas de papel, aplicando-se o inseticida nos ambientes assim vedados. Como exemplo da eficiência do sistema, Ricardo Jorge relata uma cena que, hoje, parece engraçada: numa estação telefônica, para não atrapalhar o serviço, as telefonistas foram cobertas com panos enquanto agiam os pulverizadores. ${ }^{73}$

Paralelamente transcorriam os trabalhos antilarvários em recipientes de todo tipo, nas casas e ao redor delas. Uma técnica impressionou muito o médico português: o uso de pequenos peixes larvófagos em tonéis e tinas onde se armazenava a água de beber e lavar. Ele chegou a levar para Lisboa amostras vivas de três espécies criadas em parques de piscicultura pela saúde pública. ${ }^{74}$

No relato de Ricardo Jorge sobressaem as incógnitas sugeridas pela epidemia do Rio de Janeiro, naquele momento de intensa renovação do edifício teórico e prático da febre amarela.

${ }^{70}$ Idem, ibidem p. 19 .

${ }^{71}$ JORGE, R. - La fièvre jaune et la campagne sanitaire a Rio de Janeiro... p.17.

${ }^{72}$ A esse respeito ver BENCHIMOL, J. L. - Febre amarela: a doença e a vacina...

${ }^{73}$ JORGE, R. - La fièvre jaune et la campagne sanitaire a Rio de Janeiro... p. 10-11, 17, 20.

${ }^{74}$ Idem, ibidem p. 18-19. Referência aos peixes levados para Portugal encontra-se em FUNDAÇÃO OSWALDO CRUZ ... Fundo Clementino Fraga...Carta de 10.10.1929... Sobre a campanha sanitário no Rio de Janeiro ver FRAGA, Clementino - A febre amarella no Brasil. Notas e documentos de uma grande campanha sanitária. Rio de Janeiro: Off. Graph. da Insp. de Demographia Sanitária, 1930. LINTZ, Alcides; PARREIRAS, Decio. Notas e estudos epidemiológicos sobre a febre amarela: 1928-1930. Niterói: O Cruzeiro, outubro de 1930. 
Não se podia mais negar sua endemicidade em zonas interioranas, pouco povoadas, mas como subsistia a doença lá?

$\mathrm{Na}$ capital brasileira, as estatísticas de morbidade e mortalidade corroboravam o padrão tradicional, mas as explicações antigas não satisfaziam mais. A questão racial, por exemplo. No Rio, escreveu Ricardo Jorge, "a raça é o coeficiente mais poderoso da incidência da infeção: os brancos fornecem quase o lote inteiro dos atingidos, 96\%; bem poucos mulatos, e um número insignificante de negros. $\mathrm{O}$ sangue do negro parece ser o melhor anticorpo contra o vírus. (...) Talvez se trate, não de uma imunidade racial específica,' - opinava ainda o médico português - "mas do menor gosto dos mosquitos pelos tegumentos dos negros, cujas exalações cutâneas seriam culicífugas". ${ }^{75}$

Aquela parcela da população carioca já imunizada por exposição ao 'vírus' até a campanha de Oswaldo Cruz dera lugar a muita gente recetiva, com menos de 20 anos ou recém-imigrada: 750.000 e 153.000 habitantes, respetivamente, numa população total de 1.700 .000 habitantes; destes $80 \%$ eram brasileiros, e $20 \%$, estrangeiros, a maior parte portugueses (15\%). A proporção invertia-se entre os atingidos pela doença: $22 \%$ eram brasileiros e $78 \%$, estrangeiros ( $54 \%$ portugueses). Os que habitavam o Rio há 5 anos, no máximo, correspondiam a $83 \%$ da taxa de mortalidade. ${ }^{76}$ Ricardo Jorge, o higienista que conduzira a medicina portuguesa da teoria dos miasmas à microbiana, retrocedeu ao clima para dar sentido a esse enigma: a epidemia poupara uma população em sua maior parte intocada por infeção prévia. "Por conseqüência", - escreveu -, "é preciso concluir que a estada prolongada num clima quente imuniza relativamente contra a infeção". E conjeturava: "talvez, a pele sofra alterações que a tornem menos sensíveis à virulência do Stegomyia, criando uma espécie de imunidade cutânea. Talvez, os mosquitos prefiram picar a pele fresca dos recém-chegados". ${ }^{77}$

Os fatos então descobertos na África Ocidental deflagraram um boom de estudos experimentais sobre a febre amarela, envolvendo zoólogos, entomologistas, microbiologistas e bioquímicos, com cerrada troca de informações entre Europa, América e África. No âmbito da virologia, que se desgarrava da crisálida pasteuriana, desenvolviam-se técnicas bioquímicas novas para a manipulação de seu agente, que por bom tempo permaneceu invisível e sujeito a 'n' incógnitas. Para saber se o indivíduo tinha ou não contraído a doença, passou-se a inocular seu soro num macaco para, em seguida, verificar se o protegia da infeção induzida pelo vírus. A técnica pôde ser usada em larga escala a partir de 1930, graças à descoberta de Max Theiler de que camundongos brancos eram sensíveis à infeção quando inoculados por via intracerebral. Outro método de diagnóstico retrospetivo foi convertido em procedimento utilizável por leigos em regiôes onde a violação de cadáveres era pecado dos mais graves. O viscerótomo, instrumento composto de cabo e lâmina pontiaguda para extrair fragmento do fígado de cadáveres suspeitos. Os postos de viscerotomia disseminaram-se pelo Brasil adentro, ao mesmo tempo em que se iniciavam os estudos sistemáticos de distribuição da imunidade à febre amarela por meio dos camundongos. Foram as bússolas de vasto inquérito que mostrou que a febre amarela representava problema

\footnotetext{
${ }^{75}$ JORGE, R. - La fièvre jaune et la campagne sanitaire a Rio de Janeiro... pp. 14-15.

${ }^{76}$ Idem, ibidem, pp. 11, 15.

${ }^{77}$ Idem, ibidem, p. 15.
} 
muito mais extenso do que se imaginara. Em 1933, no Brasil, Fred Soper e colaboradores verificaram que nas zonas de florestas o vírus era de fato transmitido por outros vetores além do Aedes aegypti, e tinha outros hospedeiros vertebrados além do homem. ${ }^{78}$ A chamada 'febre amarela silvestre' tornou imperativo o desenvolvimento de uma vacina, pois as medidas profiláticas tradicionais eram inaplicáveis nos novos ambientes onde ela grassava. Aquela cepa de vírus extraída do africano Asibi circulou por vários laboratórios e, depois de modificada por mais de duzentas culturas sucessivas em meios diversos, levou em 1937 ao chamado vírus 'camarada', um imunizante eficaz contra a febre amarela. No contexto africano, circularam vacinas concorrentes desenvolvidas em laboratórios europeus. ${ }^{79}$

As narrativas historiográficas sobre a campanha reestruturada no Brasil e em outros países da América a partir de 1930 mostram, em meio àquelas turbulências técnicas e sociais, a recomposição de engrenagens que logo passaram a operar de forma bem azeitada. Contudo, os relatos do delegado de Portugal no Office International d'Hygiène Publique, ancorados na experiência africana, dão-nos uma imagem bem menos estável ou consensual desse processo. Inspirado em correspondência com Henrique Aragão, do Instituto Oswaldo Cruz, Ricardo Jorge apresentou comunicação sobre a impressionante facies epidêmica daquela nova modalidade da febre amarela, a silvestre. Tomava como modelo a 'peste selvática', expressão por ele cunhada em 1928 para designar modalidade de peste bubônica recém-associada a roedores selvagens. "O homem que, na África do Sul, trabalha no veld é atacado pela peste como o lenhador que, indo à mata, contrai a febre amarela". ${ }^{80}$

Ricardo Jorge mostrou-se surpreso com a "vaga de contágio que se desloca em diversas direções a uma velocidade extraordinária”. Para Aragão, os veiculos motorizados explicavam o fenômeno, mas o médico português via naquela modalidade de febre amarela "qualidades intrínsecas de expansibilidade" ${ }^{81}$ - expressão que deixa subentendida a persistência da ideia de duas febres amarelas.

O diagnóstico dos casos suspeitos era ainda questão das mais controvertidas. Nos anos 1920, em ambos os lados do Atlântico, a grande dificuldade fora distinguir febre amarela e malária. Agora outras doenças desafiavam os recursos semiológicos disponíveis, a começar pela leptospirose, que, nos anos 1930, ganhou plena autonomia como objeto de investigação epidemiológica. A febre amarela confundia-se também com outras icterícias infeciosas ou consideradas não microbianas. Uma fora há pouco relacionada ao tetracloreto de carbono, adotado no tratamento da ancilostomíase e outros parasitas intestinais. Também se parecia, a amarela, a febre cujo vírus foi isolado em 1930 em carneiros no vale do Rift, no Quênia, pelo médico britânico George William

${ }^{78}$ SOPER, Fred L.; PENNA, H; CARDOSO, E.; SERAFIM JR, J.; FROBISHER JR, M.; PINHEIRO, J. - Yellow fever without Aedes aegypti. Study of a rural epidemic in the Valle do Chanaan, Espírito Santo, 1932. American Journal of Hygiene, Landcaster, v. 18, p. 555-87, 1933.

${ }^{79}$ Numa perspetiva essencialmente brasileira, esses estudos foram em parte analisados em BENCHIMOL, J. L. - Febre amarela: a doença e a vacina, uma história inacabada...

${ }^{80}$ JORGE, Ricardo - La fièvre jaune Selvatique au Brésil. Extrait du Bulletin mensuel de l'Office Internationale d'Hygiène Publique, tome XXX, année 1938, fasc. 1, p. $54-68$ (citação na p. 66).

${ }^{81}$ Idem, p. 60-61 
Marshall Findlay e pelo francês Georges Jean Stefanopoulo, febre qualificada como hepatite enzoótica transmissível ao homem.

Para Ricardo Jorge e seus pares no Office International d'Hygiene Publique, a viscerotomia era por demais falível no diagnóstico diferencial das lesôes no fígado causadas por essas doenças. E o testes com camundongos para investigações retrospetivas sobre a ocorrência de febre amarela em regiōes ditas 'silenciosas' também suscitavam controvérsia. ${ }^{82}$

Quando o médico português apresentou suas comunicações sobre a febre amarela nos anos 1930, a unicidade das formas silvestre e urbana não estava completamente estabelecida, e as várias espécies de vertebrados e invertebrados sensíveis ao vírus eram objetos de pesquisa em estado de ebulição. Outra questão permanecia aberta ao debate: o lugar de origem da doença. Teria a febre amarela urbana, ao penetrar nas zonas florestais, criado os focos selváticos, como supunha Ricardo Jorge que houvesse ocorrido com a peste bubônica? Ou foram as cidades do litoral invadidas pela febre amarela a partir de focos primitivos na hinterlância? Esta hipótese coadunava-se melhor com a teoria da origem americana, que ele continuava a sustentar: se era precolombiana a febre amarela, a infeção que grassava entre os indígenas à época das grandes descobertas era a selvática, que teria se urbanizado com o avanço da colonização.

\section{Conclusão}

Como vimos, essa teoria sobre a origem da doença também conhecida como 'vomito negro', 'tifo icteroide' ou 'tifo americano' prevaleceu ao longo do tempo em que foi vista como produto de miasmas e do ambiente, em seguida, de vários micróbios 'descobertos' no último quartel do século XIX. Brusca mudança de perspetiva deslocou então as atenções para o modo de transmissão da febre amarela: a demonstração de que uma espécie de mosquito era responsável por isso possibilitou a superação do impasse criado pelas controvérsias sobre sua etiologia assim como medidas práticas que por um tempo se revelaram eficazes nas cidades portuárias do litoral americano e, em menor medida, oeste-africanas. À sombra do novo paradigma floreceram outras teorias etiológicas. Se as anteriores foram talhadas à luz de analogias com doenças associadas a fungos, depois a bacilos, as novas inspiravam-se na ideia de que o agente da febre amarela devia ser um protozoário como na malária. O conceito da origem americana da febre amarela permaneceu hegemônico enquanto transcorriam campanhas visando a eliminação da doença nas zonas do globo onde se ambientava o Stegomyia fasciata (Aedes aegypti, nome disseminado nos anos 1930), supostamente o único transmissor da doença, e os humanos receptivos a ela, supostamente os únicos hospedeiros vertebrados do agente etiológico, logo identificado a um espiroqueta, à época visto por muitos especialistas como protozoário. A campanha internacional encetada

\footnotetext{
${ }^{82}$ Essas discussões constam de JORGE, Ricardo 1934 - "Sur la prospection biodémique de la fièvre jaune”. Paris, Bulletin de l'Office International d'Hygiène Publique, tome XXVI, p. 1-7; -«A propos de la fièvre jaune endémo-sporadique». Extrait du Bulletrin mensuel de l'Office International d'Hygiène Publique, tome XXVII, année 1935, fasc. 7, p. 1-5; - «La fièvre jaune africaine», extrait du Bulletin mensuel de l'Office International d'Hygiène Publique, tome XXVI, année 1934, fasc. 12, pp. 1-1.5
} 
pela Fundação Rockefeller após a Primeira Guerra esbarrou em diversas anomalias na costa ocidental da África. Ganhou força nos anos 1920 um novo ponto de vista: a febre amarela era originária da África e teria infecionado o continente americano por via do tráfico de escravos. Intensa mobilização de fontes documentais sobre a doença alimentou controvérsias entre os médicos sobre aquele objeto a um só tempo historiográfico e sanitária.

As controvérsias sobre a origem africana ou americana e sobre a identidade da febre amarela reinante em ambos os lados do Atlântico estão associadas ao desmoronamento do paradigma estabelecido na virada do século XIX para o XX

Até a sua morte, em 29 de julho de 1939, Ricardo Jorge permaneceeu envolvido com a febre amarela:

"Para todos aqueles que se ocupam dos problemas concernentes às doenças epidêmicas," - escreveu ele - "nada há de mais sedutor, de mais apaixonante ... é uma lição viva de epidemiologia e profilaxia, (...) no mais alto grau adequado a modelar o espírito e a moral de um higienista”. ${ }^{83}$

Homem longevo e bom escritor, o médico português alinhava em seus textos experiências de várias gerações. Ele visitou a capital brasileira pela primeira vez somente em 1929 - o que não deixa de ser surpreendente, considerando os pontos de contato entre a microbiologia e a saúde pública do Brasil e de Portugal proporcionados pela febre amarela, a peste bubônica e outras doenças de um modo ou de outro relacionadas ao intenso caudal humano que vinha cruzando o Attântico. As idéias externadas por Ricardo Jorge face aos enigmas colocados a partir de então pela febre amarela refletem a instabilidade criada no campo médico pela falência de conceitos que pareciam solidamente instituídos. O médico português recorre por vezes a conceitos de outro tempo para dar sentido aos fenômenos que observava, sem ter ainda clareza, como a maioria de seus contemporâneos, sobre o desfecho que teriam as anomalias que se acumulavam em ambos os lados do Atlântico.

${ }^{83}$ Idem, ibidem, p. 2. 